\title{
KOHTI REFLEKSIIVISTÄ AIKUISKASVATUSTIEDETTÄ
}

VESAHUOTARI

$\mathrm{J}$ ukka Tuomisto luonnehtii Aikuiskasvatuslehdessä (4/2002) aikuiskasvatuksen kehitystä yliopistollisena oppiaineena ja ottaa kantaa sen tilaan ja tulevaisuuteen. Haluankin hänen puheenvuoronsa pohjalta jatkaa keskustelua. Tukeudun tässä osin Alvin Gouldnerin ajatukseen refleksiivisestä sosiologiasta (Reflexive Sociology). ${ }^{1}$ Hän tarkoittaa sillä sen mahdollisuuden ottamista huomioon, että se, mikä on hyväksi sosiologeille, ei välttämättä ole sitä sosiologialle. Sosiologiaa ei välttämättä palvella palvelemalla paremmin hyvinvointivaltiota, tekemällä oman urakehityksen kannalta oikeita asioita, erottamalla tutkimuskohteet ja tutkijat toisistaan kategorisesti ja jättämällä sosiologisen analyysin ulkopuolelle se paikka, jossa ja josta sosiologien omat tietovaateet kehkeytyvät. Havaintoja vääristävät ja maailmaa dehumanisoivat uhat eivät sijoitu pelkästään sosiologien tutkimaan maailmaan (out there) vaan ovat myös läsnä sosiologiassa tutkivana maailmana (in here). Jos tavoitteena on tietää paremmin, on tiedostettava myös se persoonallinen ja institutionaalinen positio, josta uutta tietoa tavoittelee.

Gouldner yhdistääkin refleksiivisen sosiologian integriteetin sen kykyyn vastustaa kaikkia määritelmiä todellisuudesta, jotka nojaavat pelkästään esittäjän auktoriteettiin. Tässä suhteessa erityistä huomiota tulee suunnata omaan lähiympäristöön (so. oma yliopisto, oma professio, oma rooli sosiologina jne.). Tältä osin olen hyvässä asemassa: Jukka Tuomiston työhuone ei juuri voisi olla lähempänä omaani eikä hän artikkelissaan juurikaan vetoa empiiriseen näyttöön. Nähdäkseni askel kohti refleksiivisempää aikuiskasvatustiedettä on kysyä, onko se, mikä hänen mielestään aikuiskasvatuksesta puuttuu, sitä, mitä aikuiskasvatus kaipaa.

Artikkelin valossa aikuiskasvatukselta ja -kasvattajilta puuttuu identiteetti juuri aikuiskasvattajina. Syynä on Jukka Tuomiston mielestä se, että aikuiskasvattajien koulutus ei ole totaalisesti aikuiskasvattajien itsensä käsissä, että alan koulutus ei rakennu puhtaasti aikuiskasvatustieteelliselle perusrungolle, ja että alan työtehtäviä ei ole varattu juuri aikuiskasvatuksen tutkinnon suorittaneille. Hän näkeekin, että mitkä tahansa kasvatustieteen opinnot ja opettajankoulutus ohittavat nyt aikuiskasvatuksen alan eriytyneet opinnot, ja pitää tätä nurinkurisena nykyisen erikoistumisen aikana: "Täytyy vain toivoa, että kasvatustieteen edustajat ymmär-

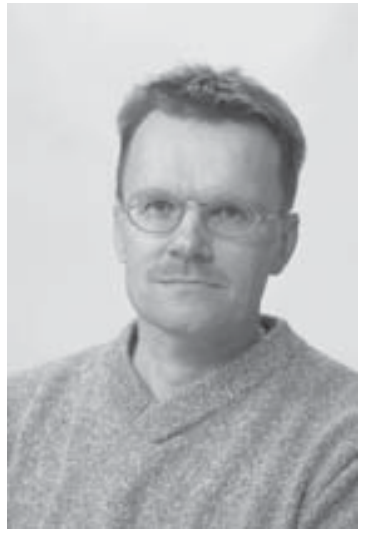

Vesa Huotari tävät vähitellen, että aikuiskasvatus tarvitsee oman koulutuksensa siinä kuin lasten ja nuorten kasvatus".

En ole vakuuttunut siitä, että "oma koulutus" on lasten ja nuorten kasvatukselle eduksi. "Omasta koulutuksesta" ensimmäiseksi hyötyvät ne, jotka sen ansiosta voivat omistautua tulevien kasvattajien kasvattamiseen.

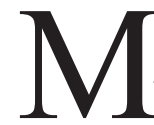
utta jatketaan Jukka Tuomiston ajatusta ja ajatellaan sitä päivää, jolloin aikuiskasvatuksen osaksi on langennut se, minkä hän katsoo siltä puuttuvan (oma identiteetti, eksklusiivinen yliopistollinen koulutusohjelma pesunkestävine aikuiskasvattajineen, ja "oman koulutuksen" suorittaneille myös omat aikuiskasvatuksen ammatilliset positiot työelämässä). Se, mihin haluaisin kiinnittää huomiota, on mahdollisuus pysäyttää eriytyminen juuri tähän pisteeseen eli eksklusiivisen, eheän ja kokonaisen aikuiskasvatuksen syntyyn. Minun on vaikea nähdä tässä mitään luonnollista päätepistettä. Olisi vaikeaa kieltäytyä suomasta sitä onnea, joka aikuiskasvatuksen osaksi olisi näin tullut, myös toisille. Täten siis perustelu, jolle aikuiskasvatuksen erityisyys rakentuisi, eriyttäisi sitä jatkossa edelleen.

Ikää on vaikea pitää erityisen vakaana lähtökohtana aikuiskasvatus- ja -koulutustehtävien 
eriyttämiselle. Aikuiskasvatuksesta eriytyisivät mahdollisesti nuoret aikuiset ja eläkeikäiset ryhminä, jotka edellyttävät erityistä ja eriytettyä asiantuntemusta ja omia koulutusohjelmiaan. Samalla tunnistettaisiin uusia erityisistä järjestelyistä hyötyviä aikuisoppijoita "erityisandragogista" asiantuntemusta vaativina ryhminä. Työssä kehittyminen puolestaan sisältyisi "ammattikasvatuksen" mandaattiin ja se pyrkisi kiistämään yleisen aikuiskasvatuksellisen koulutuksen kyvyn tuottaa asiantuntemusta ammatillisen aikuiskoulutuksen alueella. "Aikuisoppilaitoshallinto" edellyttäisi aikuisoppilaitosten rehtoreilta perehtymistä juuri oppilaitosten johtamisen kysymyksiin oman käsitteellisen kehyksensä puitteissa ja näin edelleen. Tämä johtaa absurdiin maailmaan, jossa esimerkiksi Aulis Alasen näkemys, ettei perus- ja jatkotutkinto-opiskelu yliopistossa ole aikuiskasvatusta, toimisi aikuiskasvatuksesta itsestään nousevana perusteluna sille, ettei aikuisten oppimisen ja opettamisen asiantuntijoista ole opettamaan aikuiskasvatuksessa perus- ja jatkotutkintoja suorittavia yliopisto-opiskelijoita. Aikuiskasvattajien olisi ensin perehdyttävä nuorisopedagogiikkaan tai korkeakoulupedagogiikkaan, ellei sitten korkeakouluandragogiikkaan.

Mitä aikuisuus voi tarkoittaa maailmassa, jonka joka kulmassa ja käänteessä odottaa oma akateemisesti koulutettu "asiantuntijansa" mahdollista asiakasta ja jossa inhimillisen toiminnan sfäärit pilkkoutuvat lukemattomiksi tällaisiksi "asiantuntijuuksiksi”. Kannattaako aikuiskasvattajien todella ponnistella tällaisen uljaan professionaalisen tulevaisuuden todentamiseksi? En henkilökohtaisesti näe tässä taivasta.

Konkreettinen taitaminen ja tapahtumat laboratorio-olosuhteiden ulkopuolella ovat monitieteisiä ja -määreisiä. Ajatusta "omasta" teorianrungosta ja "omasta" teorianmuodostuksesta on hyvä punnita tätä tosiasiaa vasten. Kasvatuksen alueella oma teoria, joka olisi praktisesti efektiivinen itsessään, vaikuttaa minusta yhtä absurdilta kuin ajatus maailmasta, jossa kyettäisiin sulkemaan pois kaikkien muiden paitsi esimerkiksi aikuiskasvatuksellisten lakien vaikutus. Tästä syystä "oma" teoria on taipuvainen redusoitumaan pelkäksi esoteeriseksi kielenkäytöksi. Siitä toki on mainiosti ryhmäjäsenyyden ilmentämiseen ja identiteetin rakentamiseen, mutta samalla se tuottaa korkeintaan illuusion sellaisesta praktisesta pätevyydestä, johon Jukka Tuomisto viittaa ja jonka hän ajattelee tulokseksi aidosti omas- ta koulutuksesta (pintapuolisen ja näennäisen osaamisen kritiikki, s. 271).

En kannata tieteellisen tutkimuksen redusoimista erikoistuneen akateemisen koulutuksen tukifunktioksi. Yliopisto-opetuksen perustuminen tieteelliseen tutkimukseen on nähdäkseni eri asia kuin tutkimuksen valjastaminen palvelemaan yliopisto-opetusta ja akateemisiin ammatteihin valmistamista yliopistossa. Jälkimmäisessä tapauksessa kärryt valjastetaan hevosen etupuolelle.

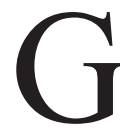
ouldnerin mukaan meillä on tarve normalisoida maailma poistamalla siitä meitä uhkaava, ei-sallittu, ja keskittymällä toivotun ja suotavan ylläpitämiseen ja vahvistamiseen. Soisimme mielellämme, että se, mitä pidämme pahana, olisi myös heikko, ja se, mitä hyvänä, olisi vahva (potentiaalinen). Täten aikuiskasvatustiede, jonka potentiaalisuus nähdään merkittäväksi, ajatellaan myös joksikin hyväksi, toivottavaksi. Informaatio, jossa toivottuun yhdistyy heikkous tai ei-toivottuun vahvuus, nähdään vihamieliseksi, jätetään huomiotta, kielletään, tai teoretisoidaan toiseksi. Refleksiivisen sosiologian tavoitteena on laajentaa kykyä ymmärtää tämä ja vahvistaa kykyä käyttää vihamieliseksi koettua informaatiota. Eteneminen kohti refleksiivistä aikuiskasvatustiedettä voisi lähteä yksinkertaisesti siitä, että ei samasteta sitä, mikä on aikuiskasvatustieteen parhaaksi, siihen, mitä aikuiskasvatuksen yliopistollisten opetus- ja tutkimusvirkojen haltijat haluavat, eikä jälkimmäistä edelleen siihen, mikä on hyväksi aikuiskasvatuksen kentällä toimiville aikuiskasvattajille itse aikuisista puhumattakaan. Jos kyky erottaa moraalinen empiirisestä on olennaista refleksiiviselle sosiologialle, on se epäilemättä sitä myös refleksiiviselle aikuiskasvatustieteelle.

\section{VIITE}

Gouldner, A. (1973). The Coming Crisis of Western Sociology. London: Heinemann. 